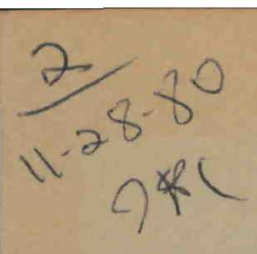

Unlimited Release

UC-78

\title{
LWR NUCLEAR POWER PLANT COMPONENT FAILURES
}

W. H. Schmidt

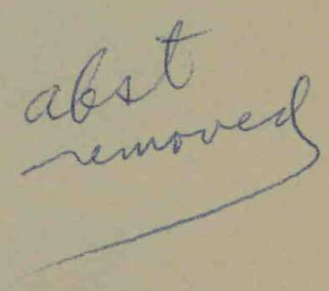

Prepared by Sandia Laboratories, Albuquerque, New Mexico 87185

and Livermore, California 94550 for the United States Department of

Energy under Contract AT(29-1)-789

Printed October 1980

\section{[17) Sandia National Laboratories}

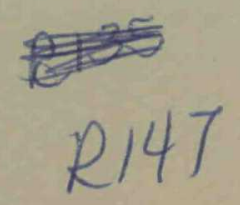


NOTICE

This report was prepared as an account of work sponsored by an agency of the United States Government. Neither the United States nor any agency thereof, nor any of their employees, makes any warranty, expressed or implied, or assumes any legal liability or responsibility for any third party's use or the results of such use of any information, apparatus, product or process disclosed in this report, or represents that its use by such third party would not infringe privately owned rights.

Printed in the Inited States of America

Available from

National Technical Information Service

U.S. Department of Commerce

5285 Port Royal Road

Springfield, VA 22161

Price: Printed Copy $\$ 5.25 ;$ Microfiche $\$ 4.00$ 


\section{DISCLAIMER}

This report was prepared as an account of work sponsored by an agency of the United States Government. Neither the United States Government nor any agency Thereof, nor any of their employees, makes any warranty, express or implied, or assumes any legal liability or responsibility for the accuracy, completeness, or usefulness of any information, apparatus, product, or process disclosed, or represents that its use would not infringe privately owned rights. Reference herein to any specific commercial product, process, or service by trade name, trademark, manufacturer, or otherwise does not necessarily constitute or imply its endorsement, recommendation, or favoring by the United States Government or any agency thereof. The views and opinions of authors expressed herein do not necessarily state or reflect those of the United States Government or any agency thereof. 


\section{DISCLAIMER}

Portions of this document may be illegible in electronic image products. Images are produced from the best available original document. 


\section{CONTEVTS}

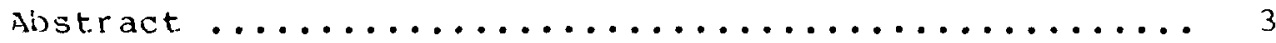

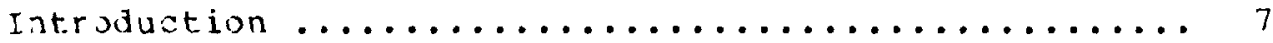

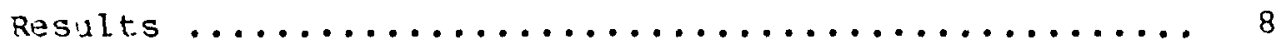

Dissussion $\ldots \ldots \ldots \ldots \ldots \ldots \ldots \ldots \ldots \ldots \ldots \ldots \ldots \ldots \ldots . \ldots \ldots \ldots$

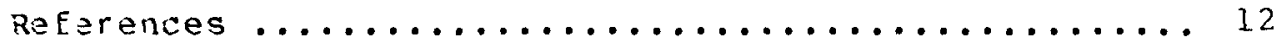

\section{TABLES}

Number

1

LWR Component. Failure Data

Erom Nuclear Safety Infurmation Center

Eiles, 1972 tinrough september $1979 \ldots \ldots 10$

II Reactor Operation Citation Numbers by Year

Froin vuclear safety Information Center

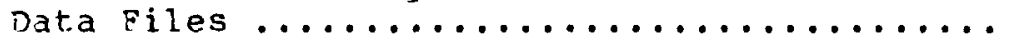




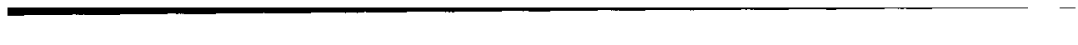


LWR NUCLEAR POWER PLANT COMPONENT FAILURES

Introduation

Data relative to the safety aspects of LWR nuclear power plant operation and performance were obtained from the computerized data bank $(1,2)$ at the Nuclear Safety Information Center (NSIC), located at the Oak Ridge National Laboratory, through the Department of Energy on line data link called RECON. By means of "key words" these data were interrogated to obtain information on the number of reports or citations for various categories of equipment in nuclear power plants. Equipinent performance is inversely related to the number of citations since the NSIC data is obtained from nuclear power plant Licensee Event. Reports (LERs) which are written orimarily in response to equipment problems.

The reactor system components which have been consilered here are nearly the same as those considered by Scott and Gallaher in "Nuclear Safety" 3 for the operating year 1976. Their data is concerned with the total number of citations or reports relative to particular components (as is part of our jata) but does not delineate the number of actual equipment failures and related reactor shutdowns.

The nomenclature and definitions used in nuclear reactor power plant operational and failure records and anslyses are not standardized. The words "report", "citation", and "accession", as associated with NSIC files, are synonyms. 4 The word "occurrence" (avoided here) is nearly always associated with a licensee event report (LER). However, starting with the yeaf 1978 , the word "occurrence", as used in "Nuclear Safety", pertains only to reportable events which involve reactor shutdown, a condition not previously required. This illustrates how the definition of a word used in the report records can be modified with time.

The key word, "failure", as used in the NSIC files, is associated with a LER pertaining to an abnormal situation which may or may not involve failure of the component to function. The subject component may be involved only indirectly in a reportable event. The problem of word definition indata systems has been pointer out by Boyle in a recent paper.

This report presents data for the total number of citations, as well as for citations related to equipment failure, which pertain to reactor shutdown. With considerations for remedial action in mind, reactor component categories which have relatively large numbers of total citations and large numbers of citations for reactor shutdowns due to component failure are highlighted. The trend of the number and rate of citations and important failures is indicated by a year-by-year breakdown of total citations and equipment failures. 
Results

Table I shows the number of databank citations due to reactor shutdowns because of failure in the various reactor component categories. This table also shows the total number of citations recorded for the various component categories. The total number of citations exceeds the total number of equipment. failures and reactor shutdowns due to failures, and is an indicator of problems with components in a given category. The calculated fractions of citations for specific component categories and the order of importance are also given for both PWR and BWR plant types.

Table II presents an overall summary of the number of citations from the NSIC databank as a function of year from 1972 through 1978 for all failures, shutdowns, and shutdowns due to component. failure. These ata also imply gross rates of failure as a function of time which apparently reach a maximum for PwRs in the year 1977 and approximately two years earlier for BWRs. This gross rate does not take into account the number of operating reactors, power level, age, etc.

The plant component with the largest number of reports or citations in the data bank is valves and likewise they are the component most responsible for reactor shutdowns. 7 The most significant findings can be summarized as follows:

1. The most important reactor component categories from the standpoint of reactor shutdown due to component failure are in the reactor coolant. systens.

PWR plants:

valves

steam generators

seals

BWR plants:

valves

seals

pipes and pipe fittings

2. From the standpoint of total citations, the most important component categories are also in the LWR coolant systems.

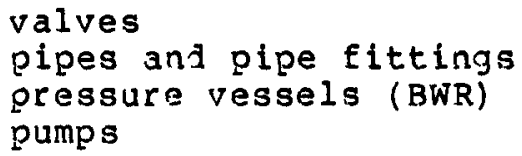

3. The gross citation numbers and rates imply continued operational difficulties in both PWR and BWR facilities with only a recent decline from peaks or plateau values. 
A comparison of the present total citation data with the 1976 data of scott and Gallaher shows that for PWRs the three highest component categories are still valves, pipes and pipe fittings, and pumps, respectively. For BWRs, however, the present data shows that the order of importance is not the same as for PWRs, as indicated by scott and Gallaher, but pumps have moved to fourth place, and thirf place is now occupied by the pressure vessel citations. The reason for the increase in pressure vessel citations has not been investigated but suggests the importance of closely following citation rates for individual components in order to afect timely remedial action.

This zeneral survey of reactor component citations is brief and far from conplete in that many parameters on which component. performance depends, such as age, reactor power level, operational history, etc., have not been considered. However, the importance of both shutdown failure citations and total citations as criteria for highlighting the effect of significant. component. problems on reactor operation is indicated. Also, the importance of categorizing by reactor types in order to properly illuminate troublesome components is indicated.

The consistently large number of incidences of component failure in essentially the same categories, from at least 1975 through september 1978, indicates a need for routine component Eailure analysis in order to encourage timely anj effective remedial action. 
Table I

LWR COMPONENT FAILURE DATA

From Nuclear Safety Information Center Files

1972 Through September 1978

\begin{tabular}{|c|c|c|c|c|c|c|c|c|c|c|c|c|}
\hline Component & \multicolumn{6}{|c|}{ Total Citations } & \multicolumn{6}{|c|}{ Reactor Shutdown Citations } \\
\hline Valves & 2567 & .175 & 1 & 2361 & .234 & 1 & 49 & .192 & 1 & 89 & .423 & 1 \\
\hline Pumps & 1681 & .115 & 3 & 779 & .077 & 4 & 27 & .106 & 4 & 11 & .052 & 6 \\
\hline Steam Generator & 1176 & .080 & 4 & 48 & .005 & 20 & 33 & .129 & 2 & 0 & .0 & 18 \\
\hline Storage Container & 957 & .065 & 7 & 363 & .036 & 10 & 3 & .012 & 13 & 0 & .0 & 19 \\
\hline Cables \& Connectors & 546 & .037 & 8 & 426 & .042 & 9 & 10 & .039 & 9 & 15 & .071 & 4 \\
\hline Seal & 519 & .035 & 9 & 468 & .046 & 7 & 31 & .122 & 3 & 27 & .129 & 2 \\
\hline Support Structure & 1034 & .070 & 5 & 690 & .068 & 5 & 2 & .008 & 16 & 2 & .010 & 13 \\
\hline Tubing & 334 & .023 & 15 & 88 & .009 & 18 & 25 & .098 & 5 & 5 & .024 & 8 \\
\hline Valve Operators & 246 & .017 & 16 & 264 & .026 & 12 & 3 & .012 & 14 & 9 & .043 & 7 \\
\hline Shock Absorbers & 191 & .013 & 18 & 195 & .019 & 15 & 1 & .004 & 18 & 0 & .0 & 20 \\
\hline $\begin{array}{l}\text { Control Rod \& } \\
\text { Drives }\end{array}$ & 413 & .028 & 12 & 460 & .046 & 8 & 19 & .075 & 6 & 3 & .014 & 12 \\
\hline Turbine & 443 & .030 & 11 & 508 & .050 & 6 & 6 & .024 & 10 & 13 & .062 & 5 \\
\hline Solenoid & 102 & .007 & 21 & 119 & .012 & 17 & 1 & .004 & 20 & 4 & .019 & 11 \\
\hline Fastener & 355 & .024 & 13 & 254 & .025 & 13 & 3 & .012 & 15 & 2 & .010 & 15 \\
\hline Pressure Vessels & 999 & .068 & 6 & $\underline{792}$ & .079 & 3 & 0 & .0 & 21 & 2 & .010 & 16 \\
\hline Total & 14662 & .998 & & 10083 & .998 & & 255 & 1.003 & & 210 & 1.001 & \\
\hline
\end{tabular}


REACTOR OPERATION CITATION NUMBERS BY YEAR

From Nuclear Safety Information Center Data Files

Category

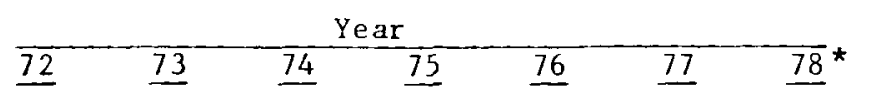

$\underline{\text { Total }}$

A11 Reactor Types

Failures

Shutd owns

Shutdowns, failure

$\begin{array}{rrrrrrr}802 & 1405 & 2143 & 2621 & 2832 & 3142 & 172 \\ 36 & 42 & 38 & 150 & 130 & 184 & 8 \\ 10 & 16 & 18 & 109 & 94 & 139 & 6\end{array}$

PWR's

$\begin{array}{lrrrrrrrrr}\text { Failures } & 250 & 535 & 842 & 1135 & 1288 & 1783 & 1040 & 6873 & 7365 \\ \text { Shutdowns } & 11 & 14 & 17 & 56 & 55 & 100 & 45 & 298 & 319 \\ \text { Shutdowns, failure } & 3 & 4 & 7 & 40 & 41 & 83 & 37 & 215 & 221\end{array}$

BWR's

$\begin{array}{lrrrrrrrrr}\text { Failures } & 411 & 685 & 976 & 1206 & 1271 & 1217 & 637 & 6403 & 7007 \\ \text { Shutdowns } & 18 & 18 & 14 & 68 & 53 & 53 & 24 & 248 & 262 \\ \text { Shutdowns, failure } & 6 & 11 & 9 & 59 & 48 & 44 & 20 & 197 & 200\end{array}$

*Through September 1978 
1. H. B. Wetsel, "Guidelines for Review anj Editors at NSIC," ORNL-NSIC-47, Nuclear Safety Information Center, Oak Ridge National Laboratory, Oak Ridge, Tennessee, January 1970 (this is a description of the system in which data files are maintained).

2. Celia Parks, Carol Julian, "Information Scanning and Reviewing at NSIC," ORNL-NSIC-48, Nuclear Safety Information Center, Oak Ridge National Laboratory, Oak Ridge, Tennessee, July 1971 (this is a description of the system in which data files are maintained).

3. R. L. Scott and R. B. Gallaher, "A Review of Safety-Related Occurcences in Nuclear Power Plants as Reported in 1976," Nuclear Safety, Volume 19, No. 1, January-February 1978 .

4. Gary Mays, private communication, Nuclear Safety Information Center, Oak Ridge National Laboratory, Oak Ridge, Tennessee, Decenber 19, 1978.

5. R. L. Scott and R. B. Gallaher, "Reportable Occurrences at Nuclear Reactors and Their Causes," Nuclear Safety, Vo1. 1, No. 1, January-February 1978.

6. Eugenia Boyle, "Opportunity for Advanced Data Collection Systems for Nuclear Power Plants," Symposium on Inservice Data Reporting and Analysis for Pressure Vessels, Piping, Punps, and Valves, San Francisco, California, December 12, 1978 .

7. W. H. Schmidt to W. A. Von Riesemann, "Analysis of Occurrences Resulting LWR Nuclear Power Plant Shutdowns Due to Valve Failure," Internal Memorandum, Sandia Laboratories, November 29,1978 . 
Distribution:

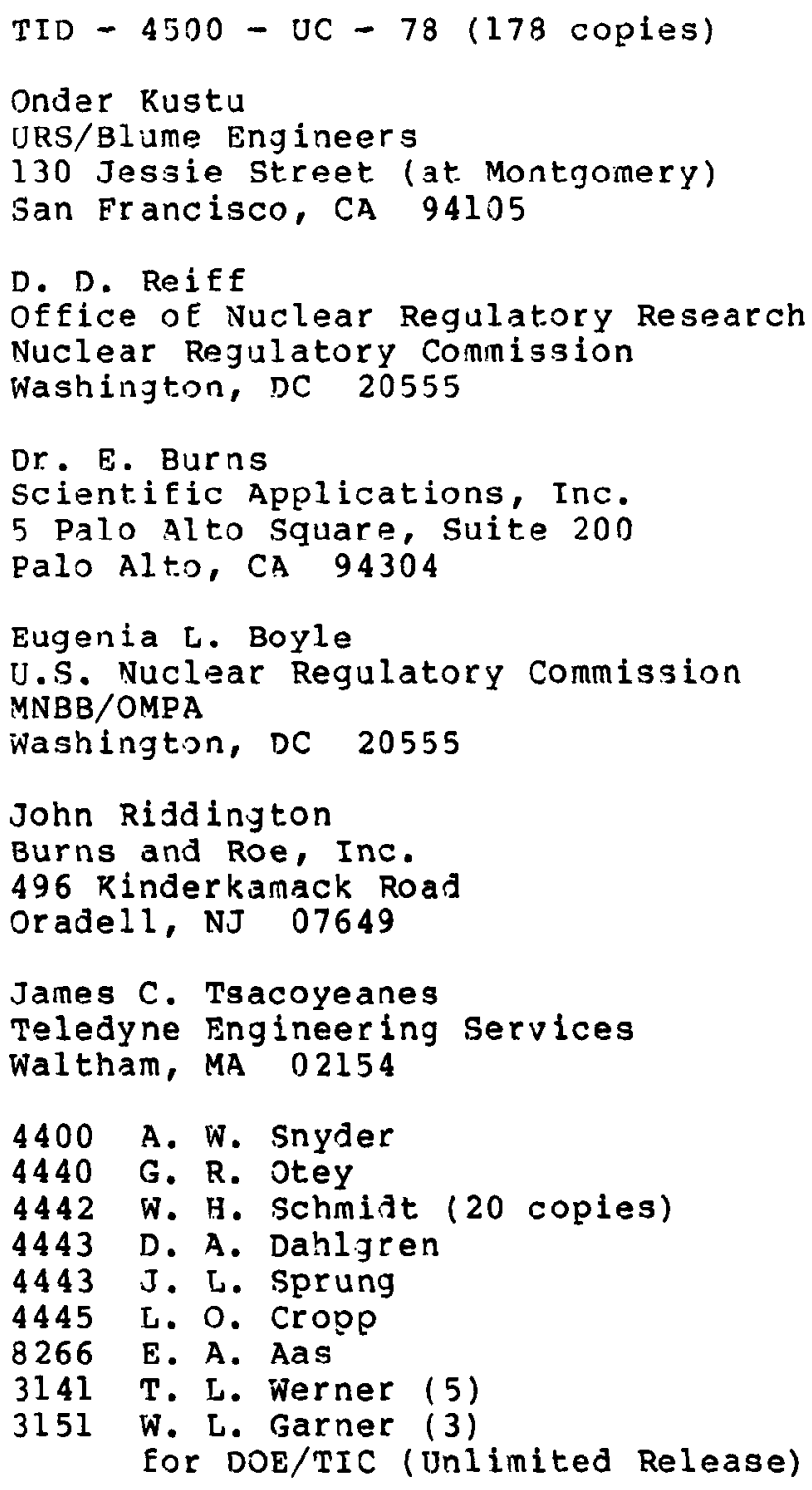

